\title{
Carl Schmitt and Ahasver. The Idea of the State and the Wandering Jew
}

\author{
Galit Hasan-Rokem
}

\begin{abstract}
In this article the cultural effects and the specific reverberations in Carl Schmitt's work of two literary figures emerging in vastly different cultural contexts in the $16^{\text {th }}$ century, Leviathan and the Wandering Jew, are analyzed using a pair of discursive concepts - political theology and Midrash.

Whereas Leviathan is an explicitly discussed figure in Carl Schmitt's work, Ahasver the Wandering Jew is a concealed figure in his writing - but, however, one that conceivably was in the range of cultural associations that he and especially the recipients of his work were exposed to. My aim is to show that whereas Schmitt was informed by the kind of stereotypical thinking embodied in the legendary and very popular figure of Ahasver, the figure itself was suppressed and replaced by a seemingly rational political discourse addressing Leviathan.
\end{abstract}

Keywords: Leviathan; Ahasver; Wandering Jew; Hobbes; Schmitt; Midrash; political theology

\section{Midrash and Politico-theological Discourse}

The title of this article has two parts. In the first line two figures, Leviathan and Ahasver, are characterized using a pair of discursive concepts - political theology and Midrash. Both figures of the first line originate in the Hebrew Bible: Leviathan is apparently a mythical beast, with some relationship to Behemoth (Kinnier Wilson 1975), and Ahasverus is the Persian king of the Book of Esther. In the second part of the title, the suggested relationship of two other well-known figures is described in terms of an ideological conflict. Some readers may instantly discern the connecting link between the two lines of the title: Ahasver or Ahasverus is also the most popular name for the legendary figure of the Wandering Jew in Central European, especially German traditions (Anderson 1965; Daube 1955). I hope to illuminate the initially perhaps somewhat enigmatic relations between the different figures - which I by no means intend to present as analogical - in the following discussion.

Whereas Leviathan is an explicitly discussed figure in Carl Schmitt's work, especially (but not only) in his The Leviathan in the State Theory of Thomas Hobbes: Meaning and Failure of a Political Symbol (Schmitt 1996; orig. 1938), Ahasver the Wandering Jew is a concealed figure in Schmitt's writing, however one that conceivably was in the range of 
cultural associations that he was exposed to. ${ }^{1}$ My aim is to show that whereas Schmitt was informed by the kind of stereotypical thinking embodied in the legendary and vastly popular figure of Ahasver, the figure itself was suppressed and replaced by a seemingly rational political discourse addressing Leviathan, and the sentiment that it roused, channeled into multiple expressions of outright anti-Semitism as well as more or less subtle anti-Semitic hints and slurs.

Schmitt's Leviathan, a less explicitly theoretical and less well-known work than e.g. his Political Theology: Four Chapters on the Concept of Sovereignty (Schmitt 2005; orig. 1922) or The Concept of the Political (Schmitt 2007; orig. 1927), parallels the major conceptualizations of his work in an attempt to introduce a specific historical perspective to his claims. Whereas Schmitt sympathizes in general with the Hobbesian understanding of human nature and its relationship to questions of sovereignty and state, he strongly criticizes the use Hobbes has made of the symbol of Leviathan. But whereas Hobbes was demonstrably well-versed in the various religious and literary traditions regarding Leviathan and thus interpreted the figure with greater versatility, Schmitt's lesser erudition and especially lesser understanding - in these traditions, as well as his suspicion - indeed aversion - against everything Jewish lead to a misreading of Hobbes and a too narrow interpretation of the Leviathan figure, consequently dismissed largely on the basis of the - in itself correct - identification of the cultural meanings of Leviathan with Jewish sources.

The theoretical and methodological standpoint from which this discussion opens is somewhat different than of philosophy, political science, legal history, modern history or even Geistesgeschichte, all highly relevant approaches to Schmitt's work including his Leviathan (certainly not to be confused with its namesake written by Hobbes). Much of the immensely rich discussion on Schmitt's conception and misconception of Hobbes delineates his genealogy mainly in the terms of the books he read and the philosophers and theologians that he studied. My intention is to show that some of the peculiarities of his approach may be additionally understood if we take into account the cultural influences and associations on both elite and popular level that he may very well have acquired in the particular milieus to which he belonged. It is thus the method of cultural semiotics as a mapping of cultural associations that I will apply. ${ }^{2}$

Moreover, I am proposing to discuss 20th (and 17th) century discourse in terms of the textual mode of Midrash inherited from antiquity, seen here not as some have suggested, as a figurative description of post-modern literary theory and interpretation (Hartman and Budick 1986, xi-xiii), but as a historically manifest tradition in European culture partly shared by Jews and Christians. A fuller historical description of the common European midrashic creativity would demand a separate article, if not more (e.g.: Levenson 1998; Shoulson 2001). This commonality of textual mode and production also emphatically

1 The correlation was first suggested to me by Dan Diner whose deep inspiration is embedded in the following discussion. David Nirenberg, Freddie Rokem and Na'ama Rokem have critically and lovingly read the text and generously contributed from their wisdom and creativity. The mistakes and misconceptions that remain are entirely mine. I thank Ottfried Fraisse for extremely well-informed and patient editing. Very special thanks to Regina Bendix.

2 Towards the end of this paper I shall engage in a short exchange of ideas with Étienne Balibar's introduction to the French translation of Schmitt's Leviathan (Balibar 2002b), which in addition to its philosophical approach also employs cultural semiotics. 
marks the common discursive roots of these two religious traditions' philosophical and cultural orientations from the earliest periods of their entanglement and co-emergence (e.g.: Yuval 2006; Boyarin 2004; Hasan-Rokem 2003). Midrash has been poetically described as an "urge to connect one's world with the world of Scripture, to find some way of dwelling, as it were, in biblical reality" (Kugel 1986, 78). More straightforwardly, it can be characterized as a genre of scriptural interpretation straddling a wide range of exegetical, rhetorical, figurative and narrative methods and techniques, producing compilations structured according to varying editorial principles related to many of the books of the Hebrew Bible (most famously the Pentateuch and the "Five Scrolls" - Song of Songs, Ruth, Lamentations, Ecclesiastes and Esther) or passages of the same genre in works mainly devoted to other genres such as legal and ritual discourses, notably the Talmudic compilations. Midrash is historically traced to Rabbinic literature of Late Antiquity (ca. 1 st -7 th centuries CE), however more than latently present already in the Hebrew Bible that serves as the dominant frame of reference for the Rabbis (Fishbane 1986) it also continues as an oral and written creative mode to the present.

While historically not all Midrash has been politico-theological discourse, and not all politico-theological discourse has been Midrash, a considerable part of Midrash is characteristically politico-theological - and thus vice versa, some politico-theological discourses are Midrash. Furthermore: by correlating Midrash and one of the overriding terms of Carl Schmitt's political philosophy - or possibly philosophical politics - I want to underline the sheer impossibility, by now widely recognized, of his exclusionist urge in some instances to almost clinically separate Jewish cultural practices from the mainstream of European cultural creativity, especially with regard to matters of state, sovereignty and politics, with which they were apparently not supposed to meddle, and where Schmitt, some of his likes and some worse than him, could decide and rule. Reading Schmitt himself - as well as Hobbes whose Leviathan he discusses in the essay devoted to that topic (Schmitt 1996) - as midrashic exegetes of biblical texts and pointing out the kinship of their writings with one of the dominant textual modes of classical Judaism, especially in its Rabbinical formation, i.e. Midrash, I shall elaborate on a central theme of my own work, namely the Jewish and Christian co-production of culture in elite as well as popular spheres. Needless perhaps to say, I have likewise considered Midrash that emerged as a central literary genre in late antiquity, albeit a characteristically Jewish genre, also a site of multifarious cultural interactions between Jews, Christians, philosophers, polytheists and possibly others (Hasan-Rokem 2000; 2003).

Let us now consider the second of the discursive terms. The first chapter of Schmitt's Political Theology: Four Chapters on the Concept of Sovereignty (Schmitt 2005; orig. 1922) opens with the almost ominous, now so famous statement: "Sovereign is he who decides on the exception" (Schmitt 2005, 5). Since I believe it is partly a midrashic construct, political theology clearly associates with interwoven Jewish and Christian discursive modes. Baruch Spinoza, who with all the complexity of his identity and fate reinforces the commonality of some major European intellectual enterprises, plays a specific role in this case. The term political theology itself, nowadays associated emphatically with Schmitt's legacy, ironically resonates loudly with "the Jew" (Schmitt's sobriquet) Spinoza's Tractatus Theologico-Politicus (Spinoza 1862; 1951). This is a fact that 
Schmitt never discloses in his essay with its almost identical title. ${ }^{3}$ Although elsewhere included in the list of the luminaries of the 17th century (Schmitt 2007, 83), here Spinoza is robbed of his apparent copyright. ${ }^{4}$

However, the term political theology itself is explicitly parsed in another sentence in the relevant book by Schmitt, the opening of chapter 3 that also has by now achieved the status of a well-known maxim: "All significant concepts of the modern theory of the state are secularized theological concepts ... " Notably the ensuing bifurcation of this sentence separates historical development from the systematic character of the said theological concepts: “... not only because of their historical development - in which they were transferred from theology to the theory of state, whereby, for example, the omnipotent God became the omnipotent lawgiver - but also because of their systematic structure, the recognition of which is necessary for a sociological consideration of these concepts" (Schmitt 2005, 36). Creating an almost a priori hiatus between the religious history of sacred language and the present, Schmitt proposes that the systematic character of theology may be extracted of its meaning and transposed as a structural principle to a different domain altogether. It is this presumed birth of modern politics from the dead spirit of religion that produces the following interesting analogy: "The exception in jurisprudence is analogous to the miracle in theology." The sovereign of the first sentence has thus been elevated to a maker of miracles, according to Schmitt, possibly a god of sorts. Congruently, Schmitt has elsewhere also repeated the Frazerian perception whereby religious concepts of magic are transformed in modernity into scientifically based technology (Schmitt 2007, 85). This does not, however, substantiate the presumed hiatus any more than the above opening sentence of chapter 3 does.

Turning by comparison to Benjamin's variation on the theme of exceptional states in his 'theses' "On the Concept of History," claiming that the states of emergency are not to be considered exceptions but rather the regular course of events (Benjamin 2003, 390), one can discern a vibrating tension between his almost desperate sense of continuity albeit a continuity of recurring breaks - and Schmitt's forcefully pronounced discontinuity by which modernity seems to take a shortcut behind the back of the Enlightenment to earlier times. ${ }^{5}$ Whereas Benjamin's historical poetics may thus allow for an exegetical discourse, particularly in the midrashic mode, as a discursive parallel to the consecutive

3 Cf. "Needless to say, Schmitt's indirect criticism of the Nazis - if it is that - was perfectly compatible with anti-Semitism, which is registered in this text by Schmitt's displacing the historical responsibility for the destruction of the Hobbesian state onto the Jewish people. As part of this argument, it is not Hobbes but "the Jew" Spinoza who makes the state into a technological instrument" (Kahn 2003, 77).

4 I wish to thank Guy Stroumsa, Martin Buber Professor of Religious Studies at the Hebrew University of Jerusalem, for sharing the search of earlier uses of the term. Despite consultations with a number of wellinformed persons, we have not found any yet and will be grateful for further advice.

5 I am aware of the slight variance between my suggestion and Horst Bredekamp's article that addresses Jacob Taubes' various somewhat inconsistent claims about the weight of Schmitt's influence on Benjamin: "In this idea, [Benjamin] saw the disparity between continuity and uniqueness expanded to include a concept of time that sought to distinguish between normality and exception" (Bredekamp, Hause and Bond 1999, 252). Cf. also Giorgio Agamben's discussion of the "debate between Walter Benjamin and Carl Schmitt on the state of exception" (Agamben 2005, 52-64). However, the present claim seems in agreement of Groh's understanding of the contrasting views of Schmitt and Hans Blumenberg (Groh 1998, 158), a fascinating topic that cannot be treated here, as well as with Pardes on the persistence of religion in post-Enlightenment culture (Pardes 2008, 6). 
states of emergency, one senses why Hobbes' Leviathan becomes a failed revelation in the eyes of Schmitt.

\section{Hobbes' Midrash of Leviathan and Schmitt's (Mis-)Use of It}

The first stage of my discussion will address the connections of political theology and Midrash in Carl Schmitt's thinking with (or rather against) Leviathan as a symbol for the body politic at large in the wake of Thomas Hobbes' work, while also investigating some of the exegetical range of Leviathan in Jewish traditions that relate to the same biblical sources that had inspired Hobbes' use of this particular figure of thought in his Leviathan (Hobbes 1994).

The figure of Leviathan seems to have occupied the imaginations of creative Jews far more than their Christian contemporaries and neighbors (Drewer 1981, 151). Schmitt seems to have a relatively wide range of references to Jewish elaborations on the Leviathan theme although he seldom mentions exact sources. ${ }^{6}$ However, even if one assumes that he had access to some of the sources, although he does not account for them clearly, what characterizes his approach towards the Jewish sources is a total misunderstanding of their genres and discursive modes. Whereas the epistemology of midrashic creativity, if you wish "the midrashic mind," excels in fragmentation, indeed seems to celebrate multivocality, even inconsistency - Schmitt extracts from his information (which he appears to know largely from secondary sources) a seemingly consistent narrative that he projects on the Jews, thus in his view a "Jewish narrative" (cf. Groh 1998, 27; 57; 89). The smallest semantic unit of the Talmudic discourse, namely the discord between two interlocutors, is not acknowledged by him anywhere. Analyzing the narrative that he thus conjures in this book, one must conclude that it is a story constructed to fit the narrative he bears in mind about the Jews, a narrative, which as I shall later try to show has much to do with the popular figure of the Wandering Jew. Schmitt imagines and constructs a Jewish counternarrative to the Christian narrative for which the Jews are now responsible and even have to bear the responsibility, and indeed the punishment.

The appearance that the figure of Leviathan makes in the first chapter of the second part of Hobbes's mighty book with the same name, published in 1651, the essay "Of Commonwealth" - following the first part "Of Man" - that is chapter xvii of the entire book (Hobbes 1994, 109) is no less than astounding (Stillman 1995, 793 records some contemporaries' shocked reactions). It is not the biblical reference per se that creates this effect, since already earlier in the book, the author resorted to ample citations from the biblical canon, the Hebrew as well as the Christian, and it is a well- known fact that the Hebrew Bible is the foundational text on which Hobbes weaves his political and indeed theological argument, thus not replacing the theological with the political - as Schmitt would have it - but indeed building a continuity and interdependence between the two realms. A quote of a longer passage from the text itself may convey some of the power of the image from Job and the way it is introduced in the book:

6 Moreover, when he does - he seems unsystematic, as where the editor-translator in Schmitt 1996, 12, note 2 points out the absence of a reference to Behemoth that Schmitt quoted on the page indicated. 
"[13] The only way to erect such a common power as may be able to defend them from the invasion of foreigners and the injuries of one another, and thereby to secure them in such sort as that by their own industry, and by the fruits of the earth, they may nourish themselves and live contentedly, is to confer all their power and strength upon one man, or upon one assembly of men. That may reduce all their wills, by plurality of voices, unto one will, which is as much as to say, to appoint one man or assembly of men to bear their person, and every one to own and acknowledge himself to be author of whatsoever he that so beareth their person shall act, or cause to be acted, in those things which concern the common peace and safety, and therein to submit their wills, every one to his will, and their judgments, to his judgment. This is more than consent, or concord: it is real unity of them all, in one and the same person, made by covenant of every man with every man, in such manner as if every man should say to every man I authorize and give up my right of governing myself to this man, or to this assembly of men, on this condition, that thou give up thy right to him, and authorize all his actions in like manner. This done, the multitude so united in one person is called a COMMONWEALTH in Latin CIVITAS. This is the generation of that great LEVIATHAN, or rather (to speak more reverently) of that Mortal God to which we owe, under the Immortal God, our peace and defence. For by this authority, given him by every particular man in the commonwealth, he hath the use of so much power and strength conferred on him that by terror thereof he is enabled to conform the wills of them all to peace at home and mutual aid against their enemies abroad. And in him consisteth the essence of the commonwealth, which (to define it) is one person, of whose acts a great multitude, by mutual covenants one with another, have made themselves every one the author, to the end he may use the strength and means of them all, as he shall think expedient, for their peace and common defence.

[14] And he that carrieth this person is called SOVEREIGN, and said to have Sovereign Power, and every one besides, his SUBJECT." (Hobbes 1994, 109)

The ceremonial almost ritual tone of the event of "the generation of that great Leviathan" associates strongly with biblical scenes of covenant, mentioned by Hobbes, such as God's with Abraham (Gen. 15, see also Hobbes 1994, xxvi:41, 197; xxv:3, 272-273). Due to the emphasis in the "generation of Leviathan" scene on the collective dimension of the covenant as well as its legal implications, it reverberates even stronger with the covenantal scene at the foot of Mount Sinai where the Israelites all as one receive the sacred laws and as a result are proclaimed a people (Ex. 19-31).

In The Biography of Ancient Israel: National Narratives in the Bible, Ilana Pardes has highlighted the communitas of the event in Victor Turner's terms as a moment of the suspending of social hierarchies (Pardes 2000, 71-73). Even though Moses seems to grow to something very similar to "that Mortal God," the monotheistic taboo prevails, while the "Immortal God" reveals himself briefly to the chosen man who represents the chosen people, but the power of revelation remains contained in its temporal and territorial limits and the sovereignty of God is reconfirmed. ${ }^{7}$ Indeed, whereas the Israelites' covenant is based on vocal participation of each individual in the covenantal vow, Hobbes denies the ability of individuals to make a direct covenant with God (Hobbes 1994,

7 The famous absence of the figure of Moses from the ritual-epic text of the Haggadah read at the celebration of the Exodus on Passover (Pessah) confirms the same. 
xiv:23, 85). And while Hobbes' ideal commonwealth is supposed to succumb, tremblingly, to the terror of Leviathan, the Israelites famously move on from the solemn covenantal scene to the, pace Pardes, playful carnival of the Golden Calf (Ex. 32). At least one of the implications of the Golden Calf transgression is to establish the status of the Israelites as a "hard necked people" (Ex. 32:9), ${ }^{8}$ who will not succumb totally to any authority, not even the divine. Foreshadowed by the wrestling of patriarch Jacob with God's angel (Gen. 32:25-30), the Golden Calf incident serves as another proper introduction to the saga of wrestling with God throughout the narrative sequence constructed in the canonical Hebrew Bible and beyond. However, Hobbes' explicit interest in the Sinai revelation focuses on the one hand exactly on the disciplinary perspective "If you will obey my voice indeed, and keep my covenant, then ye shall be a peculiar people to me" (Hobbes, 1994, xxv:5, 272-273, quoting Ex. 19:5-6; see also: xxv1:41, 188 quoting Ex. 19:12-13; 168, xxv:10; xlii:37 quoting Ex. 20:19), or, on the other hand, on the administrative perspective of extending authority to officers (Hobbes 1994, xl:7, 319 quoting Ex. 24:1-2), whereas the chorus-like poetical effect of the people's speech at Sinai is reflected in the quoted passage by implication. With all the variations, the solid exegetical basis of Hobbes' political philosophy is also well attuned with other midrashic enterprises of his contemporary compatriots, notably Milton's Paradise Lost (1667). ${ }^{9}$

But one cannot deny that it is with some perplexity that the reader is confronted with Leviathan in the above-mentioned grandiose scene. His contemporaries too were perplexed and so according to some it had attained its provocative purpose (Stillman 1995, 794; 802). Why Leviathan? And what is the ensuing effect of the choice of that mythical figure for the symbolical figure of the sovereign? Whereas Hobbes in other cases brings ample biblical proof for his suggestions and claims, the explanation of the choice of Leviathan is postponed many chapters after the covenantal scene itself in the final passage of chapter 28 "On Punishments and Rewards:"

"Hitherto I have set forth the nature of man, whose pride and other passions have compelled him to submit himself to government, together with the great power of his governor, whom I compared to Leviathan, taking that comparison out of the two last verses of the one and fortieth of Job, where God, having set forth the great power of Leviathan, calleth him King of the Proud. "There is nothing," saith he, "on earth to be compared with him. He is made so as not to be afraid. He seeth every high thing below him, and is king of all the children of pride." [Job 41:33-34] But because he is mortal and subject to decay, as all other earthly creatures are, and because there is that in heaven (though not on earth) that he should stand in fear of, and whose laws he ought to obey, I shall in the next following chapters speak of his diseases and the causes of his mortality, and of what laws of nature he is bound to obey." (Hobbes 1994, xxviii:27, 210) ${ }^{10}$

8 Also: Exodus 33:2; 33:5, 34:9; Deuteronomy 9:6; 9:13.

9 For a midrashic perspective on Milton, see Shoulson 2001.

10 In an oral presentation on Hobbes at the Zentrum für Literaturforschung in Berlin in July 2007, Carlo Ginzburg most illuminatingly emphasized the role of awe in Hobbes' moral philosophy in general and in the Leviathan in particular. Having heard the lecture, I quote the following information from an informal recording of Ginzburg's lecture: "Incidentally, in a chapter dealing with contemporary Jews and their messianic expectations, [Samuel] Purchas spoke at length of the two huge animals mentioned in the Book 
The passage provides the motivation of the choice of the biblical symbol following the verse "king of all the children of pride," which in the biblical context is not necessarily a compliment. Hobbes also communicates quite clearly that the project of overcoming the laws of nature by establishing the commonwealth will never entirely succeed, since the personified sovereign is himself subject to the laws of nature, and as the next chapter of the book shows, also to human weaknesses both physical and spiritual. One may suppose that the somewhat vague comparison is due to what one editor of the Leviathan has suggested in another instance that "here, as in many other places, Hobbes shows himself to be a man who knows his Bible well, but who cites from memory, and whose memory is selective" (Hobbes 1994, xxiv:7, note 3). However, placing Hobbes in a midrashic paradigm allows for a more generous suggestion, since Midrash always makes selections in the traditional repertoire of exegeses regarding any specific Bible passage and permits a high level of creativity outside the already established range of meanings. The midrashic act is tested by the success of the selection and the new combination to create new meanings in new contexts. Hobbes' Leviathan has certainly made it in that sense. In addition to his sheer anti-Semitic sentiment, it is thus also his blindness to Hobbes' intimacy with the midrashic paradigm that leads to Schmitt's misunderstanding of the function of the image of the Leviathan in his forerunner's oeuvre.

My doubt regarding some of Schmitt's interpretations, based on my critique of his lack of sensitivity to traditional Jewish genres and modes of expression - particularly Midrash - is supported by criticism from a poetic and rhetorical perspective, e.g. by Victoria Kahn in her fine essay revealing what she calls Schmitt's "blindness to the aesthetic dimension of ... early modern texts and early modern politics" and his "insensitivity to literary form [that] skews his reading of the foundational texts of the early modern period ... above all, Thomas Hobbes's Leviathan and Shakespeare's Hamlet" (Kahn 2003, 69). Kahn proposes that: "[u]ltimately, Hobbes failed to establish an adequate model of state power, according to Schmitt, because he chose the wrong myth. Hobbes [according to Schmitt] failed to realize that the image of the Leviathan was ambiguous: in the Bible, Leviathan is a powerful sea monster, but also one hated by the Jews" (Kahn 2003, 77). I argue that Schmitt's misreading of Hobbes is rooted exactly in that blindness that Kahn herself revealed which accounts for his inability to perceive the degree of ambiguity that the biblical text and later Jewish Bible exegesis accommodates. More precisely: Schmitt's inability to perceive Hobbes' integration of a midrashic epistemology and aesthetic, accounts for his misconstruction of the complexity of Hobbes' Leviathan. ${ }^{11}$ Moreover, Schmitt seems to have totally missed the way in which Hobbes' textual creativity aims at the assumed gap between metaphor and scientific discourse that was being probed and ingeniously bridged by various thinkers in the seventeenth century, who thus integrated rather than obliterated the monstrous aspects of metaphor (Stillman 1995, 792-793),

of Job, Leviathan and Behemoth." I wish to thank Dr. Amnon Raz-Krakotzkin for lending me his notes and for salient discussions of some of the themes of this article.

11 Some Christian traditions have integrated similar epistemologies and textual strategies. Cf. Preus' reference to Henry Lukin (1628-1719), clergyman and ejected minister "who reinforced the Puritan obsession with trivia by comparing it with Jewish exegesis: 'The Jews have a saying,' he reports, 'that there is not a tittle in the Law, but mountains hang on it.' The Jews too recognize that 'small particles are of very great moment, and much depends on a right understanding of them"' (150). Preus adds in note 31: "Exactly so does Harold Fisch ... characterize Midrash, as it proceeds the "opposite" way from Christian typology" (Preus 1991, 454). 
similar to the integration and reinterpretation of the figurative and mythical aspects of biblical discourse by the midrashic mode rather than abjuring them in the name of monotheism.

Thus the perceived notion that "[o]ne of the great paradoxes of the 17th century intellectual tradition, and part of the strangeness of Hobbes's title, is that a book setting out so mathematically to destroy metaphorical language should present itself as an extended trope, a Leviathan" (Stillman 1995, 795) should also be understood as based on the lack of awareness of the rhetorical and epistemological modes of Midrash in which any given two trains of thought do not necessarily produce a paradox, but rather polysemy and multiple layers of interpretation. The seeming contradiction between Hobbes' theory and practice is thus obliterated, without necessarily resorting to Victor Turner's anthropological concept of liminality - which, although it definitely is ingeniously applied by Stillman (Stillman 1995, 797), still seems much less in tune with Hobbes' world than Midrash. ${ }^{12}$ It is exactly in its capacity of not eradicating the metaphysical and mythical aspects of the biblical text that the midrashic mode of interpretation differs radically from allegory, in which the primary meaning of the text is transcended - rather than retained and amplified as in Midrash - as the final step of the allegorical process (Boyarin 1990, 108-110; Stern 1991, 11-12). Stillman's own beautiful definition of what he in tacit agreement with Schmitt sees as Hobbes' "failure" - ultimately for both a discursive rather than an epistemological or ethical failure - verges on a possible definition of one of the aspects of Midrash: "The textual proliferation of metaphor is comprehensible only in terms of the inevitable contradictions of such a project. The desire to erase desire, the urgent quest to discover laws for what has already been defined as the lawless, itself generates metaphors as traces of the desire that cannot be effaced" (Stillman 1995, 810).

In order to clarify this further, we need to proceed along two separate axes: looking at some of the biblical references to Leviathan that were not explicitly included by Hobbes, and reviewing some of the Jewish commentaries and interpretations of various biblical Leviathan passages. Let us first examine the Bible passages regarding Leviathan that Hobbes has not included in his explicit interpretation of the symbol, but which are present in the mind of the versed reader, some of them apparently known to Schmitt. Mentioned a few times only in the Hebrew Bible, the most detailed passage on Leviathan is the one explicitly referred to by Hobbes where the description of the enormous sea monster is staged as God's own speech chastising Job (Job 40:25-41:26). ${ }^{13}$ In a concise synopsis of the diatribe, Leviathan is great, but God is greater; Leviathan is creature, but God is Creator. Thus, in characteristically hyperbolic terms Leviathan's enormity points in all biblical references to the monster to state the much more impressive enormity of God, measuring His size by the size of the mythological opponents that He controls. Without my taking sides in the questions whether Hobbes was a believer or a heretic, royalist or subversive, the figure of Leviathan contains the message of the subjugation of any earthly ruler under God. In that sense, it is hard to consider his work as the origin for the above-mentioned

12 Notably Stillman admits that "[t]he monsters of metaphor are not easily banished, and as a consequence, Leviathan is a far less comfortable text than my partial account suggests, especially in those moments when its claims to mathematical certainty appear challenged by epistemologically loaded contradictions" (Stillman 1995, 805), and in my terms the midrashic mode mines metaphors for meaning rather than ironing them out into rational statements.

13 See also: Isaiah 27:1; Psalms 74:14; 104:26; Job 3:8. 
political theological claim of Schmitt rooted in the idea of substituting religious language with political discourse, as Hobbes' text emphatically maintains the double character of the language of sovereignty as political and religious.

The narrative of the primordial monster or dragon has been reconstructed as an Ancient Near Eastern mythical epic of theomachia, war of the gods, the remnants of which in the Hebrew Bible presumably refer to an ideological move from polytheistic to monotheistic view in the text itself. ${ }^{14}$ From the beginning, the relationship between God and Leviathan has thus modeled the representation of the clash of authorities, the clash of cultures - polytheism vs. monotheism - and the clash of creative imaginations about the sacred. We shall try to briefly investigate how much of these ancient associations have indeed remained related to the figure of Leviathan in the later stages of its appearance in the cultural discourses of Europe, in particular in the trajectory leading from Hobbes to Schmitt. Moreover, arguing the inseparability of Jewish culture from the general European, we shall suggest that the Jewish treatments of the topic can widen our understanding of these discourses.

The earliest rabbinic literature (ca. 1st - mid-3rd centuries CE) is relatively reticent about Leviathan, characteristically providing a ritual rule about its purity as food (Tosefta Hullin 3, 27; Sifra Shemini, 3), a consideration that later enabled the widespread vision of Leviathan's (or his mate's) meat as the delicacy served to the righteous in Paradise or in the world to come in general (e.g. Leviticus Rabbah, Palestine ca. 5th century CE, 13, 3, 277-278; Babylonian Talmud ca. 6th century, Bava Bathra 75a). Likewise, Leviathan's skin will also serve as a tent for the righteous in their afterlife (BT, Bava Bathra 75a; Midrash Tanhuma, Vayiqra 8). All the above of course in addition to the biblical role of serving as God's plaything, repeated numerous times by the Rabbis.

Midrash literature abides by the concept of the unity of the canon of the Hebrew Bible, synchronically read by the Late Antique Rabbis of Palestine and Babylonia - who created the Talmud and Midrash literature - rather than in a linear fashion. Verses appearing later in the text were frequently applied for enlightening and widening the meaning of earlier verses. One of the few verses in the Hebrew Bible on the Leviathan outside the Job passage mentioned above is Isaiah 27:1 "In that day, the LORD will punish with his sword, his fierce, great and powerful sword, Leviathan the gliding serpent, Leviathan the coiling serpent; he will slay the monster of the sea." The parallelism such as "Leviathan the gliding serpent, Leviathan the coiling serpent" is famously one of the stylistic characteristics of the poetry of the Hebrew Bible, but in Rabbinic literature parallelisms were often interpreted as adding "surplus meaning," diversifying the meaning of the canonical text and projecting into it the Rabbis' own mythologies and beliefs (Hasan-Rokem 2000, 45-46). In this case, the parallelism was interpreted early on to refer not to one Leviathan but to two, indeed a couple, like the following passage from the Targum Jonathan, ${ }^{16}$ read-

14 There is no general agreement about this primordial epic. A major proponent of the thesis was M.D. (Umberto) Cassuto in his writings about the ancient Canaanite epics with reference to the Hebrew Bible (Cassuto 1972-1979). For two opposed views of prominent contemporary Bible scholars, see: Talmon 1993; Zakovitch 1997.

15 Paul Ricoeur's term that describes well the midrashic explication of texts (Hasan-Rokem 2000, 31).

16 An Aramaic translation of the historical and the prophetical books of the Hebrew Bible, extant among the Rabbis of Babylonia but historically considered of Palestinian origin. 
ing the parallelism of the Isaiah verse as a key to the creation of Leviathan by extrapolating the verse through Genesis 1:21:

"'So God created the $[\mathrm{two}]{ }^{17}$ big monsters of the sea' ${ }^{18}$ Leviathan and its partner that are assigned for the day of solace 'and every living and moving thing with which the [clear ${ }^{19}$ water teems, according to their kinds', pure kinds and impure kinds, 'and every winged bird according to its kind', pure kinds and impure kinds. 'And God saw that it was good."”

An important mythological theme underlying much of Jewish thinking about Leviathan is conveyed here and connects the image of Leviathan ultimately to power. The doubling of the monster not only accumulates more meat for the 'days of solace', but also preempts Leviathan's claim of uniqueness and oneness, asserting them as the privilege of the monotheistic Creator. ${ }^{20}$ Another interpretation of the Isaiah verse that seems also highly inducive for the Hobbesian symbol of sovereignty, in a way imparted also in Schmitt's Leviathan repertoire, is the following medieval Hebrew rendering of Gen. 1:21 by Rashi: "21 "The tanninim: big fish in the sea, and a legend narrates about the Leviathan and its mate (here both masculine, but:) that were created (by God) male and female, and (He) killed the female and salted it for the righteous in the future (the next world), since if they will be fertile and multiply, the world will not survive because of them."22

Although Rashi's version focuses on the culinary preparation of Leviathan, its thrust lies in the ancient motive for God's wish to separate the Leviathan couple as an act of His power, namely the enormous destructive potential that the two of them would hold for the entire world (e.g. Babylonian Talmud, Bava Bathra 74b). I have chosen to highlight Rashi's version, since it was continuing as well as reshaping the tradition in Europe, where it may have entered into various interactions with other, non-Jewish discourses. Rashi quotes another earlier source for a rendering of Isaiah 27:1 that may illuminate our discussion: "Leviathan the gliding serpent - a king who was bragging like the first king Pharaoh, or a king who was haughty like the second king Sanherib." In this text, Leviathan is

17 The italicized text represents Genesis 1:21 in its "pure" version, the word "two" is an addition to the quote provided by the Targum as are all the other non-italicized words in the cited passage.

18 The Aramaic word is tanninaya, possibly referring to crocodiles or dragons cf. Psalms 74:14. The English translation of the New International Version has the strictly non-mythological "great creatures of the sea," which is not necessarily supported by any parallel, biblical or other. The King James Version opts for a mythological alternative: "In that day the LORD with his sore and great and strong sword shall punish leviathan the piercing serpent, even leviathan that crooked serpent; and he shall slay the dragon that is in the sea."

19 The word "clear" is an addition of the Targum, not mentioned in Genesis.

20 On the one hand, Leviathan(s) is singled out as a uniquely named and created creature, unlike the others who are listed in the Creation narrative in much broader, generic terms. On the other hand, its character inherently encompasses the end of Creation as well as the end of days, and thus associates with human death, that in narrative terms will be 'created' three chapters later in Genesis chapter four.

21 Rabbi Shlomo Itzhaqi (1040-1105) of Troyes, France, the most influential Jewish Bible exegete and Talmud commentator of all times.

22 This source, based on a number of earlier Rabbinic sources (Babylonian Talmud, Bava Bathra 74b, explicitly mentioning the castration of the male Leviathan to preempt multiplication; ibid. $75 \mathrm{~b}$ has detailed descriptions of the repast of the righteous) widens the apocalyptic perspective of the Leviathan myth already mentioned in the Aramaic translation. 
directly linked with the figure of a concrete sovereign. ${ }^{23}$ Another exegete's comparison of Leviathan to earthly monarchs seems to possibly hint at the narrative potential materialized in the plot suggested by Schmitt, where he characterizes the Jewish view of Leviathan as a gloating on the destruction of the kingdoms of the gentiles: "Leviathan, a parable on the strong kings of the idolaters (Christians). ${ }^{24}$ A daring and somewhat surprising suggestion arises in the following kabbalistic commentary that seems to attribute divine power to Leviathan: "Leviathan who is called the partner of the Shekhina." 25

The diversity of Jewish Leviathan materials is further enhanced by a few other themes, some of which are ostensibly known to Schmitt, all of which indeed address power and violence and the struggle for it. Most important of those is the fight between Behemoth and Leviathan (e.g.: Leviticus Rabbah, 13, 3; Midrash Tanhuma Shemini, 7; ibid. Nitsavim, 4; Aggadat Bereshit, 76). What for the Rabbis, initially probably served as a means of slaughtering the two enormous monsters for the apocalyptic meal (a popular scene in 13-14th century Western European Jewish manuscripts, Drewer 1981, 153) ${ }^{26}$ becomes for Schmitt a Jewish reveling on a mutual destruction of two mighty powers.

"Behemoth and Leviathan are the hunting game (Aramaic: kenigin; Greek:

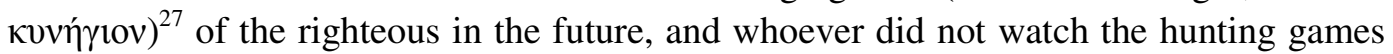
of the nations of the world (ummot ha-'olam = heathens, or even more often Christians) is entitled to see them in the world to come. How are they slaughtered? Behemoth attacks Leviathan with its horns and Leviathan attacks Behemoth with its fins and tears it apart. And the righteous say: this is an approved (ksherah) slaughter." (Leviticus Rabbah, Palestine ca. 5th century CE, 13, 3, 277-278) ${ }^{28}$

The Rabbinic author typically and cleverly plays with the double meaning of the Greek term kynegion referring both to the, for the Jews, tabooed circus games of the Romans and to the formidable feast of afterlife. The concrete culinary meaning is consequently reinforced within the context of the particular chapter whose overriding theme is

23 Rashi repeats the interpretation of Leviathan as Pharaoh also in his rendering of Psalms 74:14, correlating that to the destruction of the serpent in the Isaiah verse.

24 Rabbi David Kimhi (Provence 1160-1235) in his commentary to Isaiah 27:1, Miqra'ot Gedolot 1959, $43 a-b$.

25 Rabbi Menahem Recanati's (Italy 1250-1310) exegesis for the verse on the creation of light (Gen. 1:3), Shekhina being the female side of the divine in the myth of Kabbalah, with few early prefigurations in late antique Rabbinic literature (Scholem 1952; Patai 1964; Hasan-Rokem 2000, 128) Recanati positions Leviathan in this exegesis as the male side of the divine - the source of absolute sovereignty.

26 Drewer also suggests that the apocalyptic banquet scene was transmitted from Jewish textual tradition to Christian already in 5th-6th centuries (Drewer 1981, 155), roughly paralleling the date of the editing of Leviticus Rabbah and the earliest strata of the Babylonian Talmud.

27 This is a late form according to Liddell and Scott's Greek-English Lexicon. Notably the term also referred to animal fights in the amphitheater.

28 Cf. Schirmann 1970; N.B. Rabbi Shmuel son of Meir's (French exegete of Ramerupt, near Troyes, ca.1085-1174; grandson of Rashi on his mother's side) comment on the Babylonian Talmud version of the apocalyptic feast: "Could you assume that Moses was a kenigi or balistri? (warrior or fighter)" projecting the non-belligerent self-image at least partly dominating medieval Jewish thought as well as the image of Jews among Christian contemporaries. 
ritual kosher slaughtering, ${ }^{29}$ granted that the politics of ritual slaughtering are about imposing God's laws specifically given to Israel. With all my trust in Hobbes' erudition, it is notable that whereas the Rabbinic Leviathan is consumed by humans - albeit only the righteous ones and in a future state of being - according to the famous frontispiece of his book, Hobbes' Leviathan consists of an entity that has "devoured" all humans under its sovereignty. ${ }^{30}$

Schmitt's reading of the Leviathan texts that may indirectly be inspired by the abovementioned Rabbis' texts (or the secondary renderings of them) is ignorant of the dominant ethnographic everyday life aspect that often surprises novice readers of midrashic texts who expect a consistently "religious" text probably more familiar from Christian theological texts. Another misreading is Schmitt's ascribing of the devilish traits amply known from Christian medieval sources on Leviathan (cf. also Milton's Satan as Leviathan), ${ }^{31}$ to the Jewish understanding of the figure (Schmitt 1996, 7-10). The contrast with Jewish tradition becomes even stronger with reference to some of the narrative texts obviously unknown to Schmitt - in which Leviathan, king of the fish, serves as a wise judge with a mock Salomonic mien and bearing, and sometimes as the embodiment of the folktale motif of the knowledge of animal languages (e.g. Steinschneider 27b-28b; Bin Gorion 1990, nr.3, 5-7 and Steinschneider 4b-6a; Bin-Gorion 1990, nr. 242, 451-453; Noy 1971). The numerous manuscripts and printings of those entertaining texts demonstrate the fact that they were no less influential on Jewish imagination and mentality, if we necessarily have to pinpoint such an entity, than the texts that Schmitt indirectly refers to.

Another mystical tradition engendered in the medieval period in Europe is the cosmology portrayed in the following fragment from a longer portion in which Leviathan is actually paralleled to a saint with direct connection to divine power:

“... and the whole world stands on one pillar and its name is tsaddiq (the saint, or the righteous) as it is said (Proverbs 10:25): 'but the righteous is an everlasting foundation' which is that pillar, and the whole world is standing on one fin of Leviathan and Leviathan lives in the Lower Waters as a small fish in the water and the Lower Waters on the Primordial Waters like a spring on the shore of the ocean ..." (Batei Midrashot I, Seder Rabbah de-Bereshit, 17)

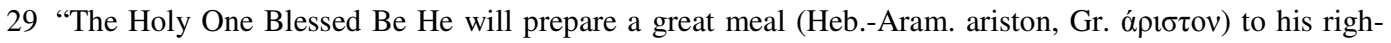
teous servants in the future and everyone who did not eat carcasses and impurities in this world will be entitled to eat in the future world." (ibid. 279)

30 Cf. Carlo Ginzburg's treatment of the illustration mentioned above in note 10.

31 This is even further reinforced by Stillman's notion that "there does appear to have been, as John Steadman argues, "a minor exegetical tradition" that links the Leviathan with prince and king, just as my own research has uncovered connections between the Leviathan and political absolutism in Puritan sermons, in: "Leviathan and Renaissance Etymology," Journal of the History of Ideas 28 (1964): 576. For the Leviathan as an icon of political absolutism, see Cornelius Burges and Stephen Marshall, Two Sermons Preached to the Honorable House of Commons Assembled in Parliament, Nov. 17, 1640 (London: By T.B. and I.O. for S. Man, P. Stephens, and C. Meredith, 1641), 42-45. But neither tradition is sufficiently strong to have prevented the vast majority of Hobbes's readers from associating the Leviathan's "dreadful Name" with the evil and the monstrous" (Stillman, 795, note 19). 
A peculiar example of a confrontational scene with Leviathan is Jonah's display of 'Abraham's covenant,' i.e. his circumcised male member to ward off Leviathan from swallowing the big fish that had swallowed the prophet - in a scene that clearly distinguishes between the two huge water creatures (Pirkei de-Rabbi Eliezer chapter 9). The mystical corpus known under the name Zohar (Book of Splendor) also includes some hints to apocalyptic clashes, mainly in repetition of what was already quoted above from late antique Rabbinic literature (e.g.: Zohar, Midrash ha-ne'elam [the Book of Concealment] I, Genesis). ${ }^{32}$

From the relatively detailed account above, it thus seems that Schmitt's interpretation of the Satanic intentions embedded in the Jewish Leviathan traditions is an exaggeration based largely on preconceived ideas and misreadings of secondary sources. One need not delve here into Schmitt's anti-Semitic views and his pragmatical as well as discursive politics, that have been amply attested already (e.g. Gross 2007), nor the odd suggestion that his book on Leviathan could actually be interpreted as a critique of the Nazi regime (McCormick 1998, 841). The last passage here will instead briefly investigate the figure of Ahasver as yet another source of information that must be taken into account as a possible influence on Schmitt's politico-theological imagination and the discursive ramifications of that influence. The total absence of the figure from Schmitt's references is, as we have already learned from his selective citing practices, not really a proof for its absence from the relevant spheres of information. In order to substantiate the possibility of the presence of the Wandering Jew image in Schmitt's associative repertoire as well as in the knowledge of his prospective readers, I shall henceforth briefly summarize the immense distribution and influence of the figure in European and especially German culture. The emphatic presence of the Wandering Jew tradition exactly from the seventeenth century onwards posits it as a popular counterpart and opposite to the contemporary emergent imaginary Leviathan.

\section{The Pervasive Presence of Ahasverus in German Culture}

One of the major creative modes of Jewish post-biblical texts is the rewritten Bible, known from Hellenistic Jewry onwards (e.g. Feldman 1998; Segal 2007). Christian authors applied the genre, adding to the rewritings of the Hebrew Bible also rewritings of the New Testament that was early on accompanied by apocryphal versions of the Gospel narratives. Oral traditions abounded with similar retellings. One of the latest to join as a folk literary version of the canonized accounts of the crucifixion is the tale known as the legend of the Wandering Jew, Ahasver (Anderson 1965; Hasan-Rokem and Dundes 1986).

The rewritten Bible has also been one of the major sources for Midrash and as such an ongoing inspiration for both Jewish and Christian authors in their midrashic creativity. Following my earlier argument here and some of my earlier work on the Wandering Jew, I shall argue that the presence of the figure in the European imagination reinforces the view by which Jewish creativity must be seen as a vital part of European culture (Hasan-

32 However the relative unimportance of the motive in medieval Jewish mysticism is proven by the absence of the term "Leviathan" from the indices of some central works in the field (Scholem 1961; Scholem 1965; Idel 1988; Idel 2002). 
Rokem 1986; 1999; 2001). Consequently Schmitt's involvement in a politico-theological discourse - as I shall claim - very possibly inspired also by this figure, demonstrates Schmitt's own deep entanglement in European Jewish creativity. But more important for the present discussion is the demonstrable ubiquity of the figure of Ahasver the wandering cobbler from Jerusalem in Central and North European popular culture especially after the Reformation of Luther.

Whereas the legend of the Wandering Jew was not initially a German invention and seminal motifs have been recorded earlier from Southern Europe, especially from Italy, it was in Germany that it gained its fullest and most detailed form and was most frequently distributed from the beginning of the seventeenth century onwards, that first century of modern Europe for which Carl Schmitt also developed a special interest. For not only the 1938 book on Leviathan relating to a major seventeenth century thinker, Hobbes, but also his post WW-II essay on Shakespeare (Schmitt 1985; orig. 1956) addresses the years of the emergence of the Ahasver tradition in the German Volksbuch, chapbook, revealing the seventeenth century as a formative stage in shaping Europe's languages of modernity. As far as we now know, the first edition of what I have called in general terms "the Legend of the Wandering Jew" was first printed in northern Germany, probably not very far from Luther's Wittenberg, in $1602 .^{33}$

The narrative opens with an event that was supposedly told to the author by the bishop of Schleswig Paulus von Eitzen, a well-known historical figure from among Luther's associates in Wittenberg. Von Eitzen told how in the winter of 1542 he met a strange figure in a church in Hamburg, a man whose mournful visage drew his attention during the sermon. The man said that his name was Ahasverus, and he had been born in Jerusalem, where he lived as a shoemaker when Jesus was driven on the Via Dolorosa to the Golgotha to be crucified. Bearing the cross He leaned on the wall of the shoemaker's house, and as Ahasverus cruelly forbade him to rest there, Jesus said to him: "I shall find rest, but you shall wander until I come again." Since then he had been wandering and could not stay in one place. The story was told to explain the heavy sighing uttered by the stranger every time the name of Christ was mentioned by the preacher. His knowledge of languages was amazing and his almsgiving generous.

It is not difficult to understand how the characterization of Ahasverus' visit in the North German church could well serve Reformation tendencies, being a live first- hand eye witness of the life of Jesus, and more importantly, of his crucifixion, a direct messenger of the very experience of revelation independent of the mediation of generations of clerics. Moreover, his behavior was heavily marked with signs of messianic fulfillment typical of popular Christianity of the period, especially the one of the conversion of the Jews that was supposed to herald the Second Coming of Christ. It seems that managing the Jews by uprooting them, as happens in the narrative of the Wandering Jew, and by making their exemplar convert, was a sign for converting them all as one possible solution, and not the worst thinkable. It was this potential of conversion and the consequent emergence of the Jewgreek (to quote Joyce's Ulysses) that seemed to have unsettled Schmitt's mind the most, as did the unbounded transgression of political borders characteristic of Ahasverus and to a certain degree practiced by the real Jews of Europe.

33 What follows is a necessarily abbreviated version of several discussions about the Wandering Jew by various scholars (Anderson 1965; Hasan-Rokem 1986; 1999; 2001; Hasan-Rokem and Dundes 1986). 
During its first century, the seventeenth, the Wandering Jew became an amazingly popular chapbook, in German, second in its popularity only to the bestselling Faustbuch (Neubaur 1912). The appearances of the Wandering Jew as a highly context-sensitive cultural product are linked to major historical, mainly military, events of each period, and to crossing borders and frontiers. The rumors about his approach would travel along with rumors regarding disasters and great changes. The distribution of the theme of the Wandering Jew was however limited neither to Germany nor to the chapbook genre and it spread fast to the Netherlands, France, England and Scandinavia. The figure also wandered in the cultural genre poly-system in painting, songs, drama, poetry and finally also novels. German and English Romanticism embraced him as an embodiment of ideals of the Aufklärung and secularization, especially of individualism - after all he wandered all alone - and somewhat surprisingly an embodiment of rebellion and critique of the religious establishment as well as other establishments.

The transformations of the Wandering Jew in the literary cultural milieu of modernity point to the extreme versatility that the theme had developed, one could claim in correlation with the capacity of the symbolical reference, namely the European Jews, to adapt to changing times in addition to their proverbial mobility in space. From the mid-nineteenth century onwards, a new phenomenon is discernible: Jewish writers too take up the figure of the Wandering Jew in their texts (Hasan-Rokem 1986), and from Schmitt's point of view a new stage of border crossing is initiated.

It is necessary here to recall that the historical research on the Wandering Jew theme (Anderson1965) has shown that the figure was not an entirely new invention of the end of the sixteenth century. Quite the contrary: Ahasver was a sophisticated amalgam of earlier religious, literary and folklore motifs. Thus, even a cursory analysis of the components of the Ahasver figure will reveal the forceful ambivalence of its sources that later contributed to the internal contradictions in his characterization and made him a highly functional sign for the ambivalent relationship of Christian Europeans to Jews, and as mentioned above, of the European Jews with regard to themselves. One should thus not overlook the Jewish elements that served the compositional process of the Wandering Jew figure in European culture. The prophet Elijah, who underwent in post-biblical Jewish tradition a transformation from the zealous fighter against the heathen priests to an itinerant helper figure frequent in folk narratives as well as in written texts, has often been pointed out as a Jewish forerunner to Ahasver. The biblical verse that most probably served as the textual point of departure for the growth of the post-biblical itinerant Elijah figure is Malakhi 4:5-6: "See, I will send you the prophet Elijah before that great and dreadful day of the Lord comes. He will turn the hearts of the fathers to their children, and the hearts of the children to their fathers; or else I will come and strike the land with a curse." Ahasver's figure was deeply infused with the selfsame mission of proclaiming the end of the days, in the Hebrew Bible reinforced by: "Remember the law of my servant Moses, the decrees and laws I gave him at Horeb for all Israel" (Malakhi 4:4), while the Christian tradition consistent with its own millenarian vision made him into the herald of Christ's second coming.

Not the least among the sources of information for the literary shaping of Ahasver was the actual process of Jews moving from one place to another, usually, but not only, as a result of frequent expulsions and harassments, also including collective murders. The history of the beggars and the peddlers of Europe accounts for the considerable number of Jews among them (Fontaine 1996). Their massive presence within the instable populations of Europe of the late Middle Ages well into the Early Modern period has among 
other things resulted in the substantial Hebrew and Yiddish components in the language of these itinerants, "Landstreicher," the Rotwelsch.

Modernity too embraced the figure of the Wandering Jew in various functions, partly making him the very emblem of modernity, ${ }^{34}$ most masterfully embodied in James Joyce's protagonist of his Ulysses, Leopold Bloom who encompasses Odysseus as well as Ahasverus.

\section{Leviathan and Ahasverus}

With this ubiquity of the Wandering Jew figure in German and Central European imagination as well as the amazing upsurge of German literary works of all genres - novels, dramas, epical and lyrical poems - bearing the name Ahasver towards the end of the nineteenth and the beginning of the twentieth century, one can hardly imagine the development of an anti-Semitic intellectual of Schmitt's capacity who was totally oblivious of its existence ${ }^{35}$ The last section of this discussion will suggest that the mighty figure of Leviathan hides in his work the much less imposing Ahasver and that Leviathan presents a possible antidote to the Wandering Jew as a social and ideological problem.

Leviathan as designed by Hobbes stands for the communal responsibility and the overriding authority of the state. Ahasver as articulated in the legends signals the ability to cross borders of states and maintain an identity the source of which lies elsewhere than the state. He is the very embodiment of the "outrage" of an identity not predicated on an unambiguous territorial definition. In a system of thought such as Schmitt's, whose ultimate proposal is to sort out enemies and friends as the great achievement of the state, the eternal border-crosser cannot be anything but anathema. Thus, the very audible antiSemitic sentiment suffusing Schmitt's text has to be complemented first with a clear vision of his theoretical rejection of the cultural position of Jews as the imaginary itinerant. Moreover, informed by the tradition of the Wandering Jew, Schmitt as many other modern Europeans was not able to integrate the unambiguous yearning of the emerging modern Jew to stop the wandering - be it by the fulfillment of communism (Kautsky 1914) ${ }^{36}$ or as too many Zionists to quote have expressed it, by the "return home," or by turning conventionally bourgeois. This explains why the worst enemies in Schmitt's eyes were those Jews who thought to embark on the journey towards a more undifferentiated European identity by performing the ultimate act of annihilating their Ahasverus-ness, by converting to Christianity and by changing their Jewish names (cf. Funkenstein 1979, 26). With the legendary Ahasverus in mind, Schmitt like his other contemporaries knew very well that the fact that the Wandering Jew appeared in the church (in Hamburg ... or elsewhere), recited pious prayers and distributed generous alms did not relieve him of the curse of eternal wandering and did not buy him a place among the burghers of the city.

34 For an especially consistent analysis of the Jew as an emblem of modern mobility, see Slezkine 2004.

35 Considerations of space do not allow for the necessary documentation, thus only a reference to a concise anthology (Körte and Stockhammer 1995) and some casual names of authors (Diehl, Jens, von Kahlenberg $=$ pseudonym of Helene Kessler) have to suffice.

36 "Ahasuerus, the Wandering Jew, will at last have found a haven of rest. He will continue to live in the memory of man as man's greatest sufferer, as he who has been dealt with most severely by mankind, to whom he has given most." (my emphasis G.H-R.) 
Noticing that "[i]t should be a permanent concern, [...] to resist the polarization of the world into the mimetic figures of Leviathan (the world-monopoly of 'legitimate' violence) and Behemoth (the ubiquitous power of subversion based on 'fundamentalist' religious creeds)" Étienne Balibar has also drawn the attention to another symbolical figure "that can be called the figure of the vanishing mediator. This is the figure (admittedly presented in speculative terms) of a transitory institution (or force, community, or spiritual formation) that creates the conditions for a new society and a new civilizational pattern, albeit in the horizon and the vocabulary of the past, and by rearranging the elements inherited from the very institution that has to be overcome" (Balibar 2002a). Claiming that "without this 'vanishing' mediation no transition from the old to the new fabric of society would have been possible" Balibar delineates some of the familiar traits associated with the Wandering Jew, such as the knowledge of many languages and an extra-national identity: "The idea of the vanishing mediator is probably not so different from the idea of the translator, the intermediary, or the traveler that I have associated with the essential function of the intellectual" quoting Eco about the practice of translation as the only genuine "idiom of Europe." It is thus not surprising that Balibar raises the tone of his voice to the utopian register, characterizing Europe as the interpreter of the world, translating languages and cultures in all directions" somehow identifying Europe with the "political function of intellectual," making intellectuals, in the best of worlds, necessary and characterized as "borderlines themselves." Balibar sets this utopian ideal as a clear contrast to the Huntingtonian clash of civilizations which he again reads as a legacy of Schmitt's "friend-foe" dichotomy. Reminiscing the numerous instances in which the Jew and especially the Wandering Jew has been set as the exemplar of modernity (e.g.: Joyce in Ulysses; Slezkine 2004) reinforces the parallel with Balibar's typological image of the intermediary.

Another possible configuration of the Leviathan-Ahasver correlation can be discerned in Victoria Kahn's suggestion that Schmitt himself projected a counter-myth to Hobbes' Leviathan - of which as we have seen he was critical - on Shakespeare's Hamlet as embodying "a pre-Hobbesian world in which heroism and tragedy are still possible ... in the context of the historical shift from medieval theology to the secular nation-state" (Kahn 2003, 83-84). Kahn points out that Schmitt thus reactivated the debate about tragedy and sovereignty that emerged between Benjamin and himself. But she proceeds to reject the myth of Schmitt's choice - Hamlet - as inadequate for his needs (thus echoing Schmitt's own dismissal of Hobbes' choice of the Leviathan myth), noting that "[i]n Hamlet, the title character is incapable of sovereignty; in Leviathan the sovereign is monstrously effective" (Kahn 2003, 86). At the same time, she somewhat ironically ponders on how Schmitt appropriated Hamlet's tragedy to illuminate his own situation during the Nazi period as "tragic." Kahn could have but did not correlate the above-mentioned incapability to reign with the affinity of Hamlet to another figure incapable of sovereignty, the Wandering Jew, both sharing the locale of Wittenberg, where the fictional Hamlet was educated and where the Reformation teleology embodied in the legendary Ahasverus' was formed (Hasan-Rokem and Rokem forthcoming).

Moving from the imaginary Wandering Jew to a real one, it should be mentioned that Bredekamp, Hause and Bond have aptly reacted to Schmitt's melancholic "Unfortunately, my attempt to respond to Benjamin by examining a great political symbol (the Leviathan...) went unnoticed" by suggesting that "[a]t first glance, it may seem questionable whether Schmitt really had Benjamin in mind when he wrote his critique of Hobbes. It is possible that he, looking back in 1973, was seeking some share in Benjamin's fame. He may have welcomed this as a welcome opportunity to disguise the book's open anti- 
Semitism by describing it as a veiled answer to a Jewish emigrant, in this way appearing to take him seriously and even honor him" (Bredekamp, Hause and Bond 1999, 261). If we accept their reading a contradiction into the relationship between Schmitt's critique of Jewish thinkers like Spinoza as contributing to the corrosion of the state, and on the other hand his own sympathy for pirates and interest in guerillas, and the dominance of the state of exception even above the principle of state sovereignty (Bredekamp, Hause and Bond 1999, 262), that would mean that there are signs of the collapse between a wouldbe Leviathan and a rejected Ahasver in Schmitt's own discourse.

Reading both Leviathan - Hobbes' own and consequently Schmitt's quite distorted one - and Ahasver - both the immensely popular one and the one suppressed by Schmitt - as traces of politico-theological Midrash, I hope to have shown the futility of Schmitt's efforts to erase Jewish culture and discursive practices from his attempts to historicize European political theory, or even from his own mindset. I shall thus conclude with a somewhat edited version of a known saying of Jews about themselves: "It is possible to force out the Jew from Europe (is it?), but it is impossible to force out Europe from the Jews.",37

\section{Bibliography}

Anderson, G.K. (1965) The Legend of the Wandering Jew. Providence: Brown University Press.

Balibar, E. (2002) Expanded version of the first George L. Mosse Lecture at HumboldtUniversität Berlin for the Academic Year 2002-2003, delivered on Thursday, November $21^{\text {st }}, 2002$. Included in We, the People of Europe? Reflections on Transnational Citizenship. Translated by James Swenson, Princeton: Princeton University Press. http://www.binghamton.edu/fbc/balibar1102.htm.

Balibar, E. (2002) Le Léviathan dans la doctrine de l'état de Thomas Hobbes: sens et échec d'un symbole politique. Introduction to Carl Schmitt, translated from the German by Denis Trierweiler, Paris: Seuil.

Benjamin, W. (1996) Selected Writings. Vol. 1 (1913-1926), edited by Marcus Bullock and Michael W. Jennings, Cambridge MA: The Belknap Press of Harvard University Press.

Benjamin, W. (2003) Selected Writings. Vol. 4 (1938-1940), translated by Edmund Jephcott and others, edited by Howard Eiland and Michael W. Jennings, Cambridge MA: The Belknap Press of Harvard University Press.

Bin-Gorion, M.J. (1990) Mimekor Yisrael. Classical Jewish Folktales. Abridged and annotated edition, edited by Emanuel Bin Gorion, translated by I.M. Lask, prepared with an introduction by Dan Ben-Amos, Bloomington IN: Indiana University Press (the German original: Der Born Judas).

Boyarin, D. (1990) Intertextuality and the Reading of Midrash. Bloomington: Indiana University Press.

Boyarin, D. (2004) Borderlines: The Partition of Judaeo-Christianity. Philadelphia: University of Pennsylvania Press.

37 The Jewish proverb is: "It is possible to force the Jew out of exile (galut), but it is impossible to force exile out of the Jew." 
Bredekamp, H. (1999) From Walter Benjamin to Carl Schmitt, via Thomas Hobbes. In: Critical Inquiry 25(2): 247-266.

Cassuto, M. D. (Umberto) (1972-79) Shirat ha-alila be-yisrael. In: Sifrut miqra'it vesifrut kna'anit, 2 vols.: 62-91.

Daube, D. (1955) Ahasver. In: Jewish Quarterly Review 43(3): 243-244.

Drewer, L. (1981) Leviathan, Behemoth and Ziz: A Christian Adaptation. Journal of the Warburg and Courtauld Institutes 44: 148-156.

Feldman, L.H. (1998) Studies in Josephus Rewritten Bible. Leiden: Brill.

Fishbane, M. (1986) Inner Biblical Exegesis: Types and Strategies of Interpretation in Ancient Israel. In: Hartman, Geoffrey H.; Budick, Sanford (eds.), Midrash and Literature. New Haven: Yale University Press, 19-37.

Fontaine, L. (1996) History of Pedlars in Europe. Translated by Vicki Whittaker, Durham: Duke University Press; Cambridge UK: Polity Press.

Funkenstein, A. (1979) The Political Theory of Jewish Emancipation. In: Grab, W. (ed.), Deutsche Aufklärung und Judenemanzipation, Beihefte zum Jahrbuch des Instituts für deutsche Geschichte 3: 13-28.

Groh, R. (1998) Arbeit an der Heillosigkeit der Welt: zur politisch-theologischen Mythologie und Anthropologie Carl Schmitts. Frankfurt am Main: Suhrkamp.

Gross, R. (2007) Carl Schmitt and the Jews: The "Jewish Question", "the Holocaust" and German Legal Theory. Translated by Joel Golb, foreword by Peter C. Caldwell, Madison: The University of Wisconsin Press.

Hartman, G.H. and Budick, S. (eds.) (1986) Midrash and Literature. New Haven: Yale University Press.

Hasan-Rokem, G. (2000) Web of Life: Folklore and Midrash in Rabbinic Literature. Translated by Batya Stein, Stanford CA: Stanford University Press.

Hasan-Rokem, G. (2003) Tales of the Neighborhood: Jewish Narrative Dialogues in Late Antiquity. Berkeley: University of California Press.

Hasan-Rokem, G. and Dundes, A. (1986) The Wandering Jew: Essays in the Interpretation of a Christian Legend. Bloomington: Indiana University Press.

Hasan-Rokem, G. (1986) The Wandering Jew - A Jewish Perspective. In: Proceedings of the Ninth World Congress of Jewish Studies, Division D, vol. 2: 189-196.

Hasan-Rokem, G. (1999) Homo viator et narrans - Medieval Jewish Voices in the European Narrative of the Wandering Jew. In: Schneider, I. (ed.), Europäische Ethnologie und Folklore im internationalen Kontext. Festschrift für Leander Petzoldt, Frankfurt am Main: Peter Lang, 93-102.

Hasan-Rokem, G. (2001) L'Image du juif errant et la construction de l'identité européenne. In: Sigal-Klagsblad, L.; Cohen, R.I. (eds.), Le juif errant: un témoin du temps. Paris: Adam Biro \& Musée d'art et d'histoire du Judaisme, 45-53.

Hasan-Rokem, G.; Rokem, F. (forthcoming) What did they do in Wittenberg? Crossroads and Intertextuality in Early Modern Europe. In: Festschrift in Honor of Professor Ziva Ben-Porat.

Hobbes, Th. (1994) Leviathan, with selected variants from the Latin edition of 1688. Edited and with introduction by Edwin Curley, Indianapolis: Hackett Publishing Company.

Idel, M. (1988) Kabbalah: New Perspectives. New Haven: Yale University Press.

Idel, M. (2002) Absorbing Perfection: Kabbalah and Interpretation. New Haven: Yale University Press.

Kahn, V. (2003) Hamlet or Hecuba: Carl Schmitt's Decision. In: Representations 83: $67-96$. 
Kautsky, K. (1914) Are the Jews a Race? http://marxists.org/archive/kautsky/1914/jewsrace/ch12.htm

Kinnier Wilson, J.V. (1975) A Return to the Problems of Behemoth and Leviathan. In: Vetus Testamentum 25(1): 1-14.

Kugel, J.L. (1986) Two Introductions to Midrash. In: Hartman, Geoffrey H.; Budick, Sanford (eds.), Midrash and Literature. New Haven: Yale University Press, 77-103.

Körte, M.; Stockhammer, R. (eds.) (1995) Ahasvers Spur: Dichtungen und Dokumente vom “Ewigen Juden.” Leipzig: Reclam.

Levenson, A. (1998) Christian Author, Jewish Book? Methods and Sources in Thomas Mann's Joseph. In: The German Quarterly 71(2): 166-178.

Leviticus Rabbah; Wayyikra Rabbah (1972) A critical edition based on manuscripts etc. by Mordecai Margulies. Jerusalem: Wahrmann.

McCormick, J.P. (1998) Review: Political Theory and Political Theology: The Second Wave of Carl Schmitt in English. In: Political Theory 26(6): 830-854.

Midrash Tanhuma (1972) With the Etz Yosef and Anaf Yosef interpretations etc. Jerusalem: Eshkol.

Miqra'ot Gedolot (1959) Including the Hebrew Bible text, Aramaic translations, and medieval commentators. Volume on the Late Prophets (Isaiah, Jeremiah, Ezekiel and the twelve minor prophets). Jerusalem: Schocken.

Neubaur, L. (1912) Zur Geschichte der Sage vom ewigen Juden. In: Zeitschrift des Vereins für Volkskunde 22: 33-54.

Noy, D. (1971) The Jewish Versions of the 'Animal Languages' Folktale (AT 670): A Typological-Structural Study. In: Scripta Hierosolymitana 22: 171-208.

Pardes, I. (2000) The Biography of Ancient Israel: National Narratives in the Bible. Berkeley: University of California Press.

Pardes, I. (2008) Melville's Bibles. Berkeley: University of California Press.

Patai, R. (1964) The Shekhina. In: The Journal of Religion 44(4): 275-288.

Preus, J.S. (1991) Secular Divination: Spiritual Biography and the Invention of the Novel. In: Journal of the American Academy of Religion 59(3): 441-466.

Schirmann, J. (1970) The Battle Between Behemoth and Leviathan According to an Ancient Hebrew piyyut. In: The Israel Academy of Sciences and Humanities IV: 327-69.

Schmitt, C. (2007) The Concept of the Political. Translated and with an introduction by George Schwab, with a foreword by Tracy B. Strong and notes by Leo Strauss, Chicago: The University of Chicago Press.

Schmitt, C. (1996) The Leviathan in the State Theory of Thomas Hobbes: Meaning and Failure of a Political Symbol. Translated by George Schwab and Erna Hilfstein, foreword and introduction by George Schwab, Westport CT: Greenwood Press.

Schmitt, C. (2005) Political Theology: Four Chapters on the Concept of Sovereignty. Translated by George Schwab, foreword by Tracy B. Strong, Chicago: University of Chicago Press.

Schmitt, C. (1985) Hamlet oder Hekuba: der Einbruch der Zeit in das Spiel. Stuttgart: Klett-Cotta.

Scholem, G. (1952) Zur Entwicklungsgeschichte des kabbalistischen Konzeption des Schechinah. In: Eranos Jahrbuch 21: 44-107 (since then republished in a number of versions in a few languages).

Scholem, G. (1961) Major Trends in Jewish Mysticism. New York: Schocken.

Scholem, G. (1965) On the Kabbalah and its Symbolism. Translated by Ralph Manheim, New York: Schocken. 
Segal, M. (2007) The Book of Jubilees: Rewritten Bible, Redaction, Ideology and Theology. Leiden: Brill.

Shoulson, J.S. (2001) Milton and the Rabbis: Hebraism, Hellenism, and Christianity. New York: Columbia University Press.

Sifra (1925) Reprint of the Venice 1545 edition. Berlin: Sefarim.

Slezkine, Y. (2004) The Jewish Century. Princeton: Princeton University Press.

Stillman, R.E. (1995) Hobbes's Leviathan: Monsters, Metaphors, and Magic. In: English Literary History 62(4): 791-819.

Spinoza, B. de (1862) Tractatus theologico-politicus, a Critical Inquiry into the History, Purpose, and Authenticity of the Hebrew Scriptures with the Right to Free Thought and Free Discussion Asserted etc. Translated from the Latin with and introduction and notes by the editor [R. Willis], London: Trübner \& Co.

Spinoza, B. de (1951) The Chief Works. Vol. 1, translated from the Latin with an introduction by R.H. W. Elwes, New York: Dover Publications.

Steinschneider, M. (1858) Alpha-Beta de-ben Sira - Alphabetum Siracidis cum expositione antique (narrations et fabulas continente). Edited from the Leyden manuscript of the book, Berlin: A. Friedländer.

Stern, D. (1991) Parables in Midrash: Narrative and Exegesis in Rabbinic Literature. Cambridge Mass.: Harvard University Press.

Stillman, R.E. (1995) Hobbes's Leviathan: Monsters, Metaphors, and Magic. In: English Literary History 62(4): 791-819.

Talmon, Sh. (1993) Did there exist a Biblical national epic? In: idem, Literary Studies in the Hebrew Bible: Form and Content. Jerusalem: Magnes, 91-112.

Tosefta. Z. (1955-1988) Edited by Moshe Shmuel, New York: The M.L. Rabinowich Institute.

Wertheimer, Shlomo Aharon (ed.) (1989) Batei Midrashot. Jerusalem: Ktav va-sefer (orig. Jerusalem: Moshe Lilienthal 1893-1897).

Yuval, I.J. (2006) Two Nations in Your Womb: Perceptions of Jews and Christians in Late Antiquity and the Middle Ages. Translated by Barbara Harshav and Jonathan Chipman, Los Angeles: University of California Press.

Zakovitch, Y. (1991) Yes, there was an Israelite epic in the Biblical period. In: International Folklore Review 8: 18-26.

[Zohar] (1973) The Anatomy of God: the Book of Concealment, the Great Holy Assembly and the Lesser Holy Assembly of the Zohar, with the Assembly of the Tabernacle. Translation, introduction, and annotations by Roy A. Rosenberg, New York: Ktav.

Galit Hasan-Rokem is Max and Margarethe Grunwald Professor of Folklore at the Mandel Institute of Jewish Studies at the Hebrew University of Jerusalem, teaching at the Department of Hebrew Literature \& the Jewish and Comparative Folklore Program.

She has in the past served as the Head of the Mandel Institute of Jewish Studies at Hebrew University; as president of the International Society for Folk Narrative Research. She is a founding member of the editorial board of Palestine-Israel Journal and she was recently elected member of the Swedish Gustav Adolf Academy for Folk Culture.

E-mail: hasanrokem@mscc.huji.ac.il 